\title{
Naturally Acquired Lactic Acid Bacteria from Fermented Cassava Improves Nutrient and Anti-dysbiosis Activity of Soy Tempeh
}

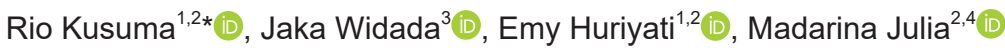 \\ ${ }^{1}$ Department of Nutrition and Health, Faculty of Medicine, Public Health and Nursing, Universitas Gadjah Mada, Yogyakarta, \\ Indonesia; '2Doctorate Program of Medicine and Health, Faculty of Medicine, Public Health and Nursing, Universitas Gadjah \\ Mada, Yogyakarta, Indonesia; ${ }^{3}$ Department of Agricultural Microbiology, Faculty of Agriculture, Universitas Gadjah Mada, \\ Yogyakarta, Indonesia; ${ }^{4}$ Department of Child Health, Faculty of Medicine, Public Health and Nursing, Universitas Gadjah \\ Mada, Yogyakarta, Indonesia
}

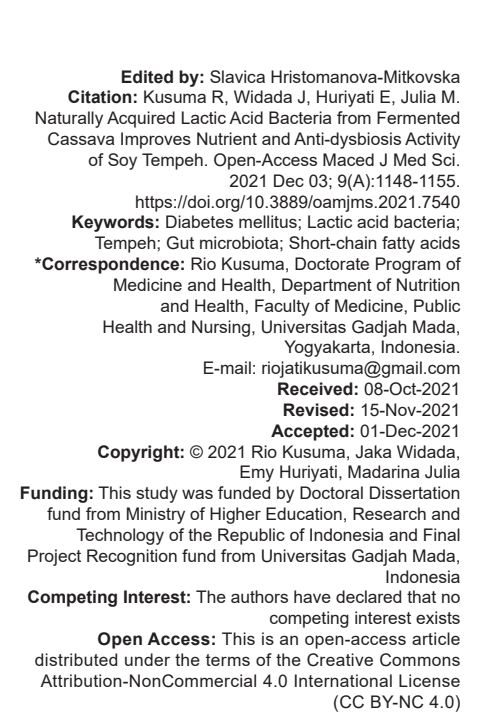

Abstract

BACKGROUND: Dysbiosis of the gut microbiota has been associated with impaired glucose metabolism. Tempeh is a traditional fermented soy food that can stimulate the growth of beneficial bacteria. In Indonesia, the process of making tempeh involved adding an acidifier that contains lactic acid bacteria. This process may affect the nutritional and anti-dysbiosis activity of tempeh.

AIM: The objective of the study was to evaluate the effects of acidifiers on the nutrient and gut microbiota profile of a diabetic animal model.

METHODS: Modified tempeh was prepared by adding water extract from fermented cassava. Standard tempeh and modified tempeh were subjected to proximate and dietary fiber analysis. Diabetic animals were fed a standard tempeh or modified tempeh diet for 4 weeks, replacing $15 \%$ or $30 \%$ of the protein in the diet, respectively. At the end of the experiment, the contents of the appendix were collected. The short-chain fatty acids (SCFAs) and microbiota composition were analyzed by 16 s rDNA next-generation sequencing.

RESULTS: There is a significant difference $(p<0.05)$ in fat, protein, water, and fiber content between regular soy tempeh and modified tempeh. There is a significant difference $(p<0.05)$ between the groups in serum glucose and SCFA composition. The diabetic animal has a low ratio of Firmicutes/Bacteroidetes. The addition of both tempehs increases bacterial diversity, Firmicutes/Bacteroidetes ratio, and SCFA-producing bacteria.

CONCLUSION: The addition of naturally occurring lactic acid bacteria from fermented cassava during tempeh processing improved both nutrient and microbiota compositions in the gut of diabetes mellitus.

\section{Introduction}

Diabetes mellitus is a group of metabolic diseases caused by a disturbance in insulin secretion, insulin action, or both, manifested by chronic hyperglycemia or high blood glucose levels [1]. Diabetes mellitus is an emerging disease with a rapidly increasing incidence worldwide. It is estimated that 451 million people worldwide had diabetes in 2017 , and this number will increase to 473 million in just 2 years [2], [3]. The increasing rise in obesity and overweight is factors associated with the sharp rise in diabetes incidence worldwide [4].

Numerous studies have reported the role of gut microbiota alterations and diversity in the development of many metabolic diseases such as diabetes mellitus [5], [6], [7]. In people with diabetes mellitus, alterations in the composition and diversity of the gut microbiota or gut dysbiosis have been found to be associated with disease. Diabetics tend to have fewer bacteria that produce short-chain fatty acids (SCFAs) and increased levels of Gram-negative bacteria such as Bacteroidetes, which promote inflammation and impaired glucose metabolism [8], [9], [10], [11]. The goal of normalizing the composition and diversity of the gut microbiota in people with diabetes mellitus has been associated with improved glycemic status in diabetic patients [12].

Tempeh is a traditional fermented soy food from Indonesia that has anti-dysbiotic activity. Several studies have reported the ability of tempeh to inhibit the growth and adhesion of pathogenic bacteria and promote the growth of beneficial bacteria such as Lactobacillus, Bifidobacterium, and Akkermansia muciniphila [13], [14], [15], [16]. Interestingly, the anti-dysbiosis activity of tempeh was affected by its processing method as previously reported by Huang et al. [17]. Conventionally, 
tempeh was produced by soaking soybeans with water or lactic acid bacteria to lower the $\mathrm{pH}$ of soy. Some tempeh producers in Indonesia used lactic acid bacteria during the souring process, which may affect the diversity of microbiota and mold composition in tempeh [18], [19], [20].

Alternatively, there are several sources of naturally acquired lactic acid bacteria that can be used to reduce the acidity of soy during the soaking phase. One of them is fermented cassava or gaplek which contain several beneficial lactic acid bacteria [21], [22]. Our preliminary study found that the addition of water extract of fermented cassava can significantly lower the $\mathrm{pH}$ of soaking water up to $4.7 \pm 0.02$ and promote the growth of Rhizopus molds. However, little is known about the effects of this modified process on the nutrient content and anti-dysbiotic activity of tempeh. Therefore, we aimed to investigate how the addition of naturally acquired lactic acid bacteria from fermented cassava affects the proximate and dietary fiber composition of tempeh, as well as the gut microbiota composition of a diabetic animal model.

\section{Methods}

\section{Preparation of the water extract of fermented cassava}

The fermented cassava tuber was obtained from the traditional market. The fermented cassava tuber was cleaned, washed, and cut into small pieces. The fermented cassava tuber was immersed in distilled water for $2 \mathrm{~h}$ at room temperature, the ratio of fermented cassava tuber to water was 1:5. The water was removed and another distilled water was added and incubated in a closed flask at room temperature for another $10 \mathrm{~h}$. After $10 \mathrm{~h}$, the mixture was filtered with a sterile cheesecloth to obtain the water extract of fermented cassava tuber.

\section{Preparation of modified tempeh}

Soybean was obtained from the local market. Tempeh was developed with modifications according to our previous study [23]. Briefly, the soybean was cleaned, washed, and immersed in distilled water for $2 \mathrm{~h}$. The soybean was boiled for $15 \mathrm{~min}$ and dehulled. The water extract of fermented cassava was added in the ratio of 1:5 and incubated in a closed vessel for $10 \mathrm{~h}$. The water extract was removed and the dehulled soybean was boiled in sterile distilled water for another $15 \mathrm{~min}$. The soybean was air dried and $2 \mathrm{~g}$ of a commercial tempeh mold (Raprima)/kg soybean was added. The soybean was aerobically incubated for $72 \mathrm{~h}$ to obtain modified tempeh. The modified tempeh was dried, milled, and sieved through 70 mesh sieves to obtain modified tempeh flour. Regular tempeh (Kadar) from the local market was also subjected to lipoylation using a similar method to that used for modified tempeh. This manufacturer was selected because it uses acidifiers from cooked soybeans in the second soaking of tempeh. Both tempeh flours were stored at $4^{\circ} \mathrm{C}$ before use.

\section{tempeh \\ Proximate and dietary fiber analysis of}

Proximate analysis of tempeh was carried out according to Cempaka et al. [24]. Total protein was analyzed using Kjeldahl with a protein conversion factor of 5.71. Fat was determined by Soxhlet method using ether as extracting agent. Moisture content was determined by thermogravimetric method. Dietary fiber was analyzed by the enzymatic gravimetric method using AOAC 991.43 [25]. All analyses were performed in triplicate.

\section{Animal and diet}

Thirty (30) male Wistar rats aged 8 weeks were purchased from the Centre of Nutrition and Food Science, PAU, Universitas Gadjah Mada, Indonesia. These numbers were obtained from Arifin and Zahirudin [26] equation. Rats were housed in groups (5 rats/cage) for 5 days during the acclimation period. The cage was $1800 \mathrm{~cm}^{2}$ wide and $24 \mathrm{~cm}$ high. The rats were given food (AIN -93M standard diet) and water ad libitum. Room temperature was set at $22^{\circ} \mathrm{C}$, humidity at $70 \%$, and lighting on a $12 \mathrm{~h}$ dark-light cycle.

After the acclimation period, 25 rats were injected with nicotinamide $230 \mathrm{mg} / \mathrm{kg}$ body weight followed by streptozotocin $65 \mathrm{mg} / \mathrm{kg}$ body weight after $15 \mathrm{~min}$ of the first injection [27]. Five rats served as control group. Blood was drawn for serum glucose pre-test 4 days after injection after overnight fasting. The diabetic rats were randomly divided into five diet groups: Rats were fed a standard diet (negative control), a modified standard diet in which $15 \%$ and $30 \%$ of protein were replaced with tempeh (TP -15 and TP -30), and a modified standard diet in which $15 \%$ and $30 \%$ of protein were replaced with modified tempeh (TG-15 and TG-30). The composition of the animal diets is shown in Table 1. Randomization was performed using the Microsoft Excel program.

After 4 weeks of treatment, blood was drawn from the overnight fasting rats for post-test analysis of serum glucose level. The rats were euthanized by injection of ketamine (100 mg/kg body weight) and xylazine $(10 \mathrm{mg} / \mathrm{kg}$ body weight) followed by cervical dislocation. The appendix was removed from each rat and immediately used for DNA isolation. All animal experiments were approved by the Ethics Committee of the Faculty of Medicine, Public Health and Nursing, Universitas Gadjah Mada, Yogyakarta, Indonesia, under ethics number KE/FK/0918/EC/2020. 
Table 1: Animal diet composition

\begin{tabular}{llllll}
\hline Composition $(\mathrm{g} / \mathrm{kg})$ & Standard diet & TP-15 diet & TP-30 diet & TG-15 diet & TG-30 diet \\
\hline Corn starch & 62.07 & 56.18 & 48.86 & 57.72 & 52.41 \\
Casein & 14.0 & 11.9 & 9.80 & 11.9 & 9.80 \\
Sucrose & 10.0 & 10.0 & 10.0 & 10.0 & 10.0 \\
Cellulose & 5.00 & 1.80 & - & 2.02 & - \\
Soybean oil & 4.00 & 2.86 & 17.12 & 28.52 & 17 \\
AlN-93 vitamin mix & 1.00 & 1.00 & 10 & 10 & 10 \\
AlN-93 mineral mix & 3.50 & 3.50 & 35 & 35 & 35 \\
L-Sistine & 0.18 & 0.18 & 0.18 & 1.8 & 1.8 \\
Choline bitartrate & 0.25 & 0.25 & 0.25 & 2.5 & 2.5 \\
Tempeh & - & 12.35 & 24.70 & - & - \\
Modified tempeh & - & - & - & 10.58 & 21.16 \\
\hline
\end{tabular}

TP-15: Diabetic rats received regular tempeh replacing $15 \%$ of protein in the diet, TP-30: Diabetic rats received regular tempeh replacing $30 \%$ of protein in the diet, TG-15: Diabetic rats received modified tempeh replacing $15 \%$ of protein in the diet, TG-30: Diabetic rats received modified tempeh replacing $30 \%$ of protein in the diet.

\section{Cecal SCFA}

About 100 mg of cecal content were homogenized with $1 \mathrm{ml}$ of deionized water. The mixture was sonicated and centrifuged at $14,000 \times \mathrm{g}$ for $10 \mathrm{~min}$. The supernatant was collected and injected into the Thermo Scientific Trace 1310 gas chromatography (GC) coupled to the Thermo Scientific ISQ LT single quadrupole mass spectrometer (MS). The injector temperature was set to $260^{\circ} \mathrm{C}$, the ion source to $230^{\circ} \mathrm{C}$, the quadrupole to $150^{\circ} \mathrm{C}$, and the $\mathrm{GC} / \mathrm{MS}$ interphase to $280^{\circ} \mathrm{C}$. Helium was used as the carrier gas.

\section{Cecal total DNA isolation}

Total DNA from the cecum was isolated using the modified FavorPrep Stool DNA Isolation Mini Kit (Favorgen, Taiwan). Briefly, $100 \mathrm{mg}$ of cecum was weighed and homogenized in lysis buffer using Precellys homogenizer (Bertin instrument, France). Approximately $100 \mu \mathrm{l}$ of $1 \mathrm{mg} / \mathrm{ml}$ lysozyme (Sigma-Aldrich, Singapore) was added to the mixture and incubated at $37^{\circ} \mathrm{C}$ for $2 \mathrm{~h}$ in a water bath. Proteinase $\mathrm{K}$ was added according to the instructions in the kit and incubated at $55^{\circ} \mathrm{C}$ for $8 \mathrm{~h}$. Samples were processed according to the manufacturer's instructions. The quality and quantity of DNA was checked using a nanodrop (MaestroNano Pro MN -913A, Taiwan).

\section{Amplicon generation}

16S rRNA from the V3-V4 region was barcoded amplified with specific primers (forward: 5-CCTAYGGGRBGCASCAG-3 and reverse: 5-GGACTACNNGGGTATCTAAT-3). All polymerase chain reaction $(P C R)$ reactions were performed using Phusion High Fidelity PCR Master Mix (New England Biolabs) according to the manufacturer's instructions. The PCR products were run in a $2 \%$ agarose gel and the samples with a bright major band between 450 and $470 \mathrm{bp}$ were selected for further experiments. The gel was purified using Qiagen Gel Extraction Kit (Qiagen, Germany) and libraries were prepared using NEBNEXT Ultra TM DNA Library Preparation Kit for Illumina. The purified amplicons were sequenced in Illumina NovaSeq 6000 in pairs.

Raw tags were merged and filtered using FLASH (version 1.2.7) and QIIME (version 1.7.0) to obtain high-quality clean tags. The tags were compared with the reference database (Gold Database) using UCHIME algorithm and chimeras were removed to get effective tags. The effective tags were analyzed using Uparse software to obtain OTU. For each representative sequence, Mothur software was used to obtain a species annotation for each taxonomic rank. The phylogenetic relationship of all OTUs was determined using MUSCLE.

\section{Data analysis}

Proximate, dietary fiber, and antioxidant activity of tempeh were analyzed using the independent samples t-test when normality of the data was met according to Kolmogorov-Smirnov test. The Friedman and Wilcoxon non-parametric tests were used to analyze the diversity index and relative abundance of major bacterial phyla and families among groups [28]. Principal component analysis (PCA) was performed to discriminate the differences of the gut microbiome between groups. Analysis of molecular variance (AMOVA) was performed to analyze the differences in gut microbiota between groups. Significant was set at $p<0.05$. All statistical analyses were performed in $\mathrm{R}$.

\section{Results}

\section{Proximate, dietary fiber, and antioxidant activity of tempeh}

There is a significant difference $(p<0.001)$ between regular tempeh and modified tempeh in water content, protein, fat, and antioxidant activity. There were also differences $(p=0.002)$ in dietary fiber between tempeh, with the highest dietary fiber content found in modified tempeh $(8.20 \pm 0.19 \%)$. Modified tempeh has higher fat, protein, and fiber content compared to normal tempeh (Table 2).

\section{Effect of tempeh supplementation on serum glucose}

There is a significant difference $(p<0.001)$ in fasting serum glucose before and after treatment. After induction of diabetes mellitus, blood glucose was significantly increased and was above $200 \mathrm{mg} / \mathrm{dl}$ in all rats, indicating successful induction of diabetes mellitus in the animals (Figure 1).

\section{Effect of tempeh supplementation on SCFA}

There are significant differences $(p<0.001)$ in the composition of SCFA (acetate, propionate, and 
Table 2: Proximate, dietary fiber, and antioxidant activity of tempeh*

\begin{tabular}{llll}
\hline Variable & Groups & & p-value \\
\cline { 2 - 3 } & Regular tempeh & Modified tempeh & \\
\hline Moisture & $63.17 \pm 0.08$ & $57.34 \pm 0.13$ & $<0.001$ \\
Crude protein & $17.03 \pm 0.02$ & $19.85 \pm 0.02$ & $<0.001$ \\
Fat & $9.27 \pm 0.01$ & $10.85 \pm 0.06$ & $<0.001$ \\
Dietary fiber & $5.92 \pm 0.02$ & $8.20 \pm 0.19$ & 0.002 \\
\hline "Data were presented in mean \pm standard deviation $(n=3)$. & &
\end{tabular}

butyrate) between the groups. Acetate and propionate in the caeca were significantly higher in diabetic rats treated with modified tempeh replacing $30 \%$ of the protein in the diet (TG-30) than in the other groups. However, the cecal butyrate of this group was not statistically different from that of the healthy control group, the group with modified tempeh or the group with normal tempeh replacing $15 \%$ of the protein in the diet (Table 3).

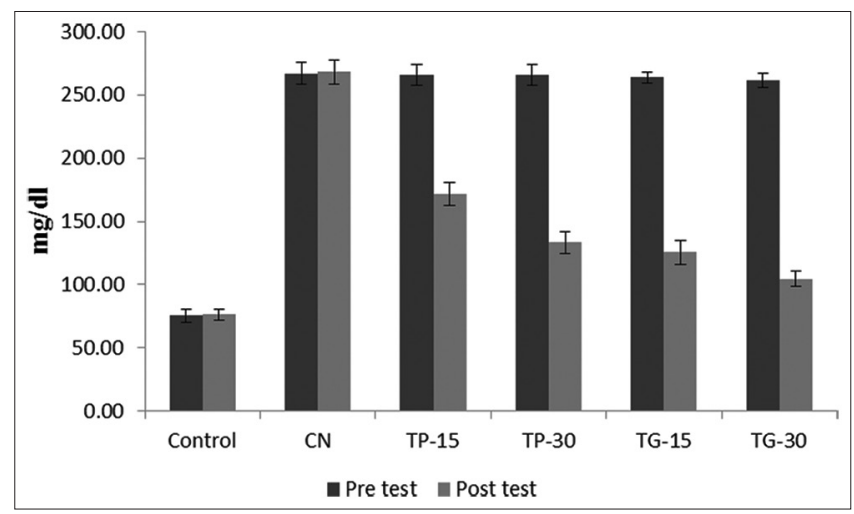

Figure 1: Effect of tempeh supplementation on fasting serum glucose before and after 4 weeks of treatment. Control: Healthy control group, CN: Diabetic control group, TP-15: Diabetic rats received regular tempeh diet replacing $15 \%$ of protein in the diet, TP-30: Diabetic rats received regular diet replacing $30 \%$ of protein in the diet, TG-15: Diabetic rats received modified tempeh diet replacing $15 \%$ of protein in the diet, TG-30: Diabetic rats received modified tempeh diet replacing $30 \%$ of protein in the diet

\section{Effect of tempeh supplementation on gut microbiota diversity}

There is a significant difference $(p<0.05)$ between the groups in terms of Shannon, Simpson, and phylogenetic diversity indices (pd) for the whole tree. There are no significant differences between groups in Chao1 index. Diabetic rats in TP30 and TG30 groups have similar Shannon and Simpson diversity index. However, TG30 was significantly different $(p<0.05)$ from healthy control group in pd whole tree diversity index (Table 4).

\section{Gut microbiota composition}

There is a significant difference $(p=0.039)$ in the composition of the gut microbiota between the groups as shown by the AMOVA test. There is no significant difference in the relative abundance of each bacterium between the groups, either at phylum or family level. At phyla level, the gut microbiota of diabetic rats consisted mainly of Bacteroidetes (36.31\%) followed by Firmicutes $(23.72 \%$ ) and Proteobacteria $(17.35 \%)$. The ratio of Firmicutes/Bacteroidetes was 0.65 in the diabetic group. Treatment of diabetic rats with normal tempeh or modified tempeh increased the abundance of Firmicutes (29.47-46.49\%) and Actinobacteria (11.58-27.33\%). Both tempeh supplements also decreased the abundance of Bacteroidetes (22.55-32.31\%) and Proteobacteria (7.5-14.29\%). Under these conditions, the ratio of Firmicutes/Bacteroidetes increased, with the highest ratio found at TG-30 (1.93).

At family level, the diabetic animals had higher abundance of Muribaculaceae (17.27\%), Bacteroidaceae (13.63\%), and Fusobacteria (11.67\%). Both tempeh supplementations increased the abundance of Prevotellaceae (8.06-17.07\%) and Lachnospiraceae (10.40-17.77\%), while decreased the abundance of Fusobacteria (0.3-5.3\%) and Bacteroidaceae (1.26-3.99\%). The composition of the gut microbiota is shown in Table 5.

The relative abundance of each bacterium is shown in Figure 2. The composition of microbiota between groups was analyzed and compared based on the relative abundance of OTUs using PCA. The first two results of PCA, PC1 and PC2, can explain $15.35 \%$ and $11.86 \%$ of the variance, respectively (Figure 3 ). Among the treatment groups, the rats fed with normal tempeh or modified tempeh replacing $30 \%$ of the protein in the diet formed one group and were separated from the other groups.

\section{Discussion}

This is the first study to investigate the effects of using lactic acid bacteria during tempeh processing on nutrient, SCFA, and gut microbiota composition in diabetes mellitus. Our study shows that modified tempeh has higher dietary fiber content compared to normal tempeh. Interestingly, although modified tempeh has higher nutrient and fiber composition than normal tempeh, both tempehs can increase the diversity of the gut microbiota of diabetic animal model. Both tempehs also show a similar trend in gut microbiota composition, that is, less Bacteroidetes and Proteobacteria and more Firmicutes and Actinobacteria compared to diabetic rats.

In the past, soaking soybeans with acidifiers such as acetic or lactic acid has been reported to increase the quality of tempeh by inhibiting the growth of pathogenic bacteria such as Listeria monocytogenes, Bacillus cereus, Salmonella infantis, Staphylococcus aureus, and Escherichia coli [29]. In addition, soaking soybeans in water can lower the $\mathrm{pH}$ and promote the growth of Enterococcus, 
Table 3: Cecal short-chain fatty acid composition $(\mathrm{mmol} / \mathrm{g})$

\begin{tabular}{|c|c|c|c|c|c|c|c|}
\hline \multirow[t]{2}{*}{ Short-chain fatty acids } & \multicolumn{6}{|l|}{ Groups } & \multirow[t]{2}{*}{$p$-value } \\
\hline & Control & Negative control & TP-15 & TP-30 & TG-15 & TG-30 & \\
\hline Acetate & $26.23 \pm 2.74^{\mathrm{a}}$ & $13.5 \pm 3.17^{b}$ & $12.13 \pm 1.23^{b}$ & $26.2 \pm 3.03^{\mathrm{a}}$ & $41.4 \pm 2.62^{\mathrm{C}}$ & $64.98 \pm 8.96^{\mathrm{d}}$ & $<0.001$ \\
\hline Propionate & $11.1 \pm 4.57^{\mathrm{a}}$ & $5.1 \pm 0.83^{\mathrm{ab}}$ & $3.84 \pm 2.01^{b}$ & $11.4 \pm 3.84^{\mathrm{abc}}$ & $13.78 \pm 2.75^{\mathrm{ac}}$ & $21.58 \pm 3.15^{d}$ & $<0.001$ \\
\hline Butyrate & $2.83 \pm 1.00^{\mathrm{a}}$ & $0.5 \pm 0.24^{\mathrm{ab}}$ & $4.93 \pm 1.35^{\mathrm{ac}}$ & $2.18 \pm 0.89^{\text {abd }}$ & $2.53 \pm 0.74^{\mathrm{abc}}$ & $4.58 \pm 1.63^{\mathrm{ac}}$ & $<0.001$ \\
\hline
\end{tabular}

Data are presented in mean+standard deviation abc ${ }^{\text {ab }}$ ifferent annotation indicating significant different $(p<0.05)$ based on Tukey-Kramer post hoc test. Notes: Control: Non-diabetic control group, negative control: Diabetic

control group, TP-15: Diabetic rats received tempeh replacing $15 \%$ of protein in the diet, TP-30: Diabetic rats received tempeh replacing $30 \%$ of protein in the diet, TG-15: Diabetic rats received modified tempeh replacing

$15 \%$ of protein in the diet, TG-30: Diabetic rats received modified tempeh replacing $30 \%$ of protein in the diet.

Table 4: Microbiota diversity of diabetic rats treated with tempeh*

\begin{tabular}{|c|c|c|c|c|c|c|}
\hline \multirow[t]{2}{*}{ Diversity index } & \multicolumn{6}{|l|}{ Group } \\
\hline & Control & Negative control & TP-15 & TP-30 & TG-15 & TG-30 \\
\hline Shannon & $4.92 \pm 1.25^{\mathrm{a}}$ & $5.90 \pm 0.64^{\mathrm{a}}$ & $6.38 \pm 0.20^{\mathrm{a}}$ & $6.76 \pm 0.23^{b}$ & $5.77 \pm 0.46^{\mathrm{a}}$ & $6.95 \pm 0.49^{b}$ \\
\hline Simpson & $0.87 \pm 0.05^{\mathrm{a}}$ & $0.93 \pm 0.03^{\mathrm{a}}$ & $0.96 \pm 0.02^{b}$ & $0.97 \pm 0.01^{\mathrm{bc}}$ & $0.94 \pm 0.02^{\mathrm{a}}$ & $0.98 \pm 0.01^{\circ}$ \\
\hline Chao1 & $823.96 \pm 202.14^{\mathrm{a}}$ & $1111.99 \pm 201.47^{\mathrm{a}}$ & $1015.69 \pm 17.95^{\mathrm{a}}$ & $1266.08 \pm 348.19^{\mathrm{a}}$ & $951.97 \pm 123.52^{\mathrm{a}}$ & $1033.41 \pm 68.55^{\mathrm{a}}$ \\
\hline Phylogenetic Diversity (PD) whole tree & $68.05 \pm 12.48^{\mathrm{a}}$ & $89.08 \pm 15.95^{\mathrm{ab}}$ & $77.54 \pm 4.67^{\mathrm{ab}}$ & $87.33 \pm 13.66^{\mathrm{ab}}$ & $94.15 \pm 17.96^{\mathrm{ab}}$ & $102.42 \pm 9.73^{\mathrm{b}}$ \\
\hline
\end{tabular}

Lactococcus, Pediococcus, Weissella, and conditions have been reported to affect the growth Enterobacter in the soaked water [30], [31]. These of tempeh mold and the nutritional composition of

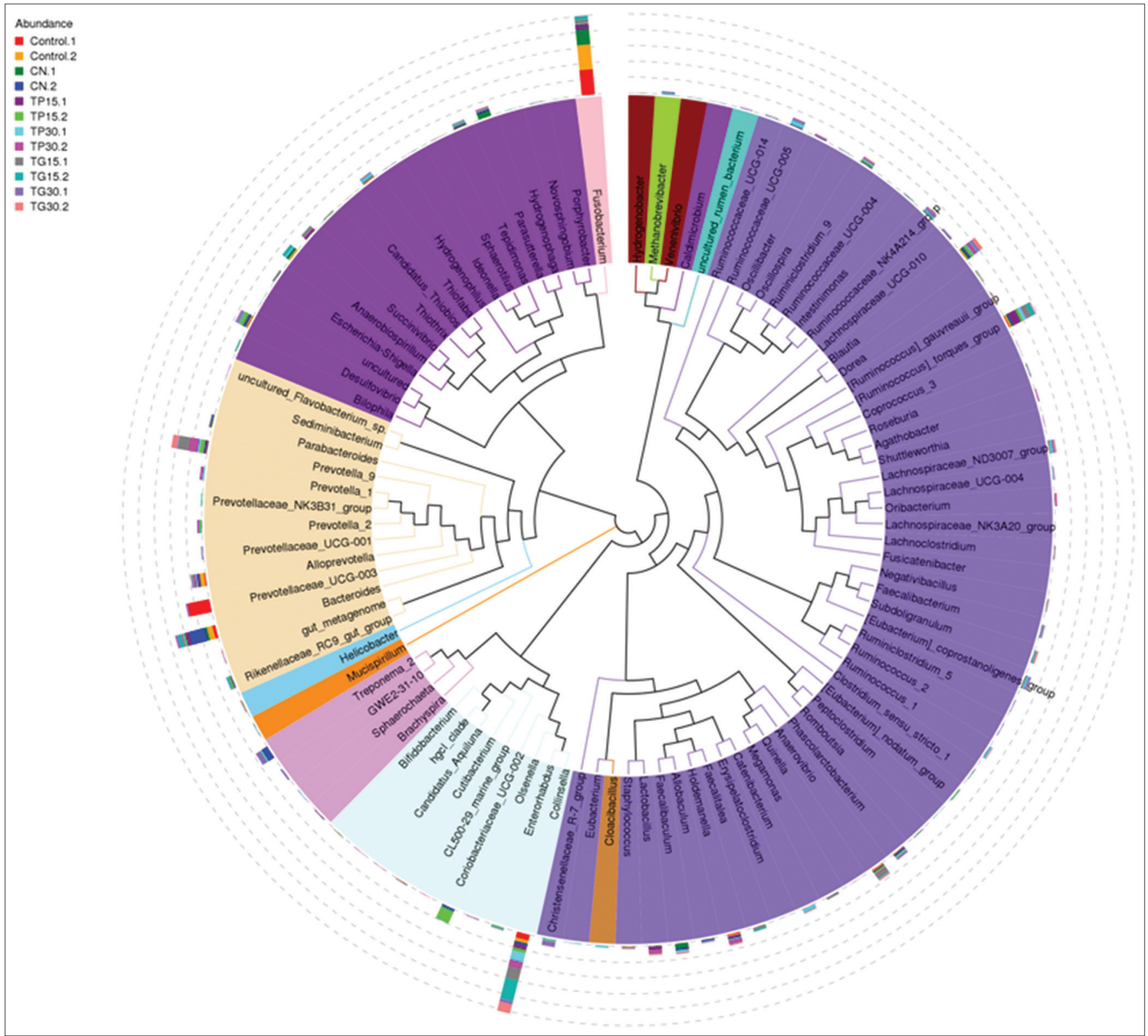

Figure 2: Relative abundance of 100 genera in response to tempeh treatment. Different colors of the branch inside the circle represent different phyla. Relative abundance of each genus in each group was displayed outside the circle. 
Table 5: Relative abundance (\%) of top 5 gut microbiota in the cecal of rats

\begin{tabular}{|c|c|c|c|c|c|c|c|}
\hline \multirow[t]{2}{*}{ Microbiota } & \multicolumn{6}{|l|}{ Group } & \multirow[t]{2}{*}{$p$-value } \\
\hline & Control & $\mathrm{CN}$ & TP-15 & TP-30 & TG-15 & TG-30 & \\
\hline \multicolumn{8}{|l|}{ Phylum } \\
\hline Firmicutes & 13.85 & 23.72 & 37.07 & 41.58 & 29.47 & 46.49 & 0.08 \\
\hline Bacteroidetes & 34.18 & 36.31 & 27.48 & 32.31 & 22.55 & 23.99 & 0.68 \\
\hline Fusobacteria & 36.46 & 11.68 & 3.73 & 0.30 & 5.26 & 0.40 & 0.11 \\
\hline Proteobacteria & 6.22 & 17.35 & 12.71 & 7.76 & 14.28 & 7.48 & 0.13 \\
\hline Actinobacteria & 7.86 & 4.11 & 17.02 & 14.79 & 27.34 & 11.58 & 0.23 \\
\hline Ratio F/B & 0.41 & 0.65 & 1.35 & 1.29 & 1.31 & 1.94 & 0.19 \\
\hline \multicolumn{8}{|l|}{ Family } \\
\hline Fusobacteria & 36.46 & 11.67 & 3.72 & 0.28 & 5.26 & 0.41 & 0.11 \\
\hline Prevotellaceae & 20.96 & 2.23 & 8.06 & 17.07 & 10.85 & 7.68 & 0.51 \\
\hline Coriobacteriaceae & 6.57 & 1.79 & 5.28 & 1.18 & 24.45 & 9.19 & 0.14 \\
\hline Bacteroidaceae & 6.09 & 13.63 & 3.99 & 1.26 & 3.15 & 2.12 & 0.43 \\
\hline Lachnospiraceae & 5.62 & 8.09 & 17.77 & 15.03 & 10.40 & 17.31 & 0.10 \\
\hline
\end{tabular}

meh, in particular the moisture, fat, carbohydrate and fiber content [32], [33], [34].

The lactic acid bacteria in tempeh are also an important aspect for the enhancement of aglycone isoflavones due to the presence of the enzyme $\beta$-glucosidase [35]. It has been reported that aglycone isoflavone stimulates the growth of Gram-positive bacteria such as Firmicutes, Lactobacillus, Bifidobacteria, Lachnospiraceae, and Coriobacteriaceae [15], [36], [37], which was also found in this study. The high number of Lachnospiraceae in the tempeh-fed group was associated with high production of SCFA from fermentation of carbohydrates [38], while high number of Coriobacteriaceae indicated high equol production from isoflavones [39].

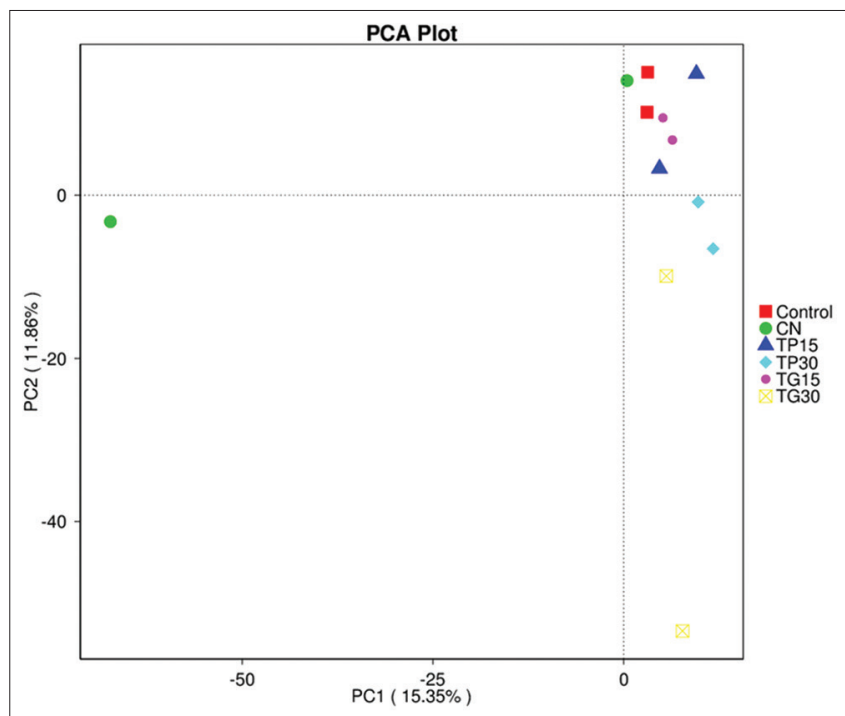

Figure 3: Principal component analysis plot of cecal microbiome samples. The first component (PC1) explained $15.35 \%$ of the total variance while the PC2 - 11.86\%. The same labels indicate samples from similar group

In addition, consumption of tempeh also increased the abundance of Prevotella, which was previously reported by another group [17]. High abundance of Prevotella was found in the intestines of people who consumed a high proportion of plant foods [40], [41], [42], and this effect was associated with the anti-inflammatory and antidiabetic effects of plant foods [43], [44].

\section{Conclusion}

Modifying the preprocessing of tempeh has implications for the nutrients, fiber, and antioxidants of tempeh. Consumption of tempeh favors the growth of the gut microbiota, which was important for the antidiabetic effect of tempeh. Further studies are needed to investigate the effects of tempeh supplementation on the composition and function of the gut microbiota in a human study.

\section{Acknowledgment}

We thank Mr. Yulianto for helping us with animal treatment.

\section{References}

1. Punthakee Z, Goldenberg R, Katz P. Definition, classification and diagnosis of diabetes, prediabetes and metabolic syndrome. Can J Diabetes. 2018;42 Suppl 1:S10-5. https://doi. org/10.1016/j.jcjd.2017.10.003

PMid:29650080

2. ChoNH, Shaw JE, Karuranga S, Huang Y, da Rocha Fernandes JD, Ohlrogge AW, et al. IDF diabetes atlas: Global estimates of diabetes prevalence for 2017 and projections for 2045. Diabetes Res Clin Pract. 2018;138:271-81. https://doi.org/10.1016/j. diabres.2018.02.023 PMid:29496507

3. Saeedi P, Petersohn I, Salpea P, Malanda B, Karuranga S, Unwin N, et al. Global and regional diabetes prevalence estimates for 2019 and projections for 2030 and 2045: Results from the international diabetes federation diabetes atlas, $9^{\text {th }}$ edition. Diabetes Res Clin Pract. 2019;157:107843. https:// doi.org/10.1016/j.diabres.2019.107843

PMid:31518657

4. Boles A, Kandimalla R, Reddy PH. Dynamics of diabetes and obesity: Epidemiological perspective. Biochim Biophys Acta Mol Basis Dis. 2017;1863(5):1026-36. https://doi.org/10.1016/j. bbadis.2017.01.016

PMid:28130199

5. Grigorescu I, Dumitrascu DL. Implication of gut microbiota in diabetes mellitus and obesity. Acta Endocrinol (Buchar). 2016;12(2):206-14. https://doi.org/10.4183/aeb.2016.206 PMid:31149088

6. Harsch I, Konturek P. The role of gut microbiota in obesity and Type 2 and Type 1 diabetes mellitus: New insights into "old" diseases. Med Sci (Basel). 2018;6(2):32. https://doi. org/10.3390/medsci6020032

PMid:29673211

7. Gurung M, Li Z, You H, Rodrigues R, Jump DB, Morgun A, et al Role of gut microbiota in Type 2 diabetes pathophysiology. EBioMedicine. 2020;51:102590. https://doi.org/10.1016/j. ebiom.2019.11.051

PMid:31901868 
8. Larsen N, Vogensen FK, van den Berg FW, Nielsen DS Andreasen AS, Pedersen BK, et al. Gut microbiota in human adults with type 2 diabetes differs from non-diabetic adults. PLoS One. 2010;5(2):e9085. https://doi.org/10.1371/journal. pone.0009085

\section{PMid:20140211}

9. Qin J, Li Y, Cai Z, Li S, Zhu J, Zhang F, et al. A metagenome-wide association study of gut microbiota in type 2 diabetes. Nature. 2012;490(7418):55-60. https://doi.org/10.1038/nature11450 PMid:23023125

10. Sun W, Zhang D, Wang Z, Sun J, Xu B, Chen Y, et al. Insulin resistance is associated with total bile acid level in Type 2 diabetic and nondiabetic population: A cross-sectional study. Medicine (Baltimore). 2016;95(10):e2778. https://doi. org/10.1097/MD.0000000000002778

\section{PMid:26962776}

11. d'Hennezel E, Abubucker S, Murphy LO, Cullen TW. Total lipopolysaccharide from the human gut microbiome silences toll-like receptor signaling. mSystems. 2017;2(6):e00046-17. https://doi.org/10.1128/mSystems.00046-17

PMid:29152585

12. Houghton D, Hardy T, Stewart C, Errington L, Day CP, Trenell MI, et al. Systematic review assessing the effectiveness of dietary intervention on gut microbiota in adults with Type 2 diabetes. Diabetologia. 2018;61(8):1700-11. https://doi.org/10.1007/ s00125-018-4632-0

PMid:29754286

13. Roubos-van den Hil PJ, Nout MJ, van der Meulen J, Gruppen H. Bioactivity of tempe by inhibiting adhesion of ETEC to intestinal cells, as influenced by fermentation substrates and starter pure cultures. Food Microbiol. 2010;27(5):638-44. https://doi. org/10.1016/j.fm.2010.02.008

PMid:20510782

14. Roubos-van den Hil PJ, Dalmas E, Nout MJR, Abee T. Soya bean tempe extracts show antibacterial activity against Bacillus cereus cells and spores. J Appl Microbiol. 2010;109(1):137-45. https://doi.org/10.1111/j.1365-2672.2009.04637.x PMid:20002864

15. Kuligowski M, Jasińska-Kuligowska I, Nowak J. Evaluation of bean and soy tempeh influence on intestinal bacteria and estimation of antibacterial properties of bean tempeh. Pol J Microbiol. 2013;62(2):189-94.

PMid:24053022

16. Stephanie S, Kartawidjajaputra F, Silo W, Yogiara Y, Suwanto A Tempeh consumption enhanced beneficial bacteria in the human gut. Food Res. 2018;3(1):57-63.

17. Huang YC, Wu BH, Chu YL, Chang WC, Wu MC. Effects of Tempeh Fermentation with Lactobacillus plantarum and Rhizopus oligosporus on streptozotocin-induced Type II diabetes mellitus in rats. Nutrients. 2018;10(9):1143. https://doi. org/10.3390/nu10091143

PMid:30135362

18. Seumahu CA, Suwanto A, Rusmana I, Solihin DD. Bacterial and fungal communities in tempeh as reveal by amplified ribosomal intergenic sequence analysis. HAYATI J Biosci. 2013;20:65-71.

19. Pisol B, Nuraida L, Abdullah N, Suliantari, Khalil KA. Isolation and characterization of lactic acid bacteria from indonesian soybean tempeh. Int Proc Chem Biol Environ Eng. 2013;58:32-6.

20. Radita R, Suwanto A, Kurosawa N, Wahyudi A, Rusmana I. Metagenome analysis of tempeh production: Where did the bacterial community in tempeh come from? Malaysian J Microbiol. 2017;13(4):280-82. Available from: https://www. semanticscholar.org/paper/metagenome-analysis-of-tempehproduction\%3a-where-did-radita-suwanto/7bbf4d74c4b1eaa93 74bf29364671bee8f8af6ad [Last accessed on 2021 Jun 23].
21. Nuraida L. A review: Health promoting lactic acid bacteria in traditional Indonesian fermented foods. Food Sci Hum Wellness. 2015;4:47-55.

22. Astriani A, Diniyah N, Jayus J, Nurhayati N. Phenotypic identification of indigenous fungi and lactic acid bacteria isolated from 'gatot' an Indonesian fermented food. Biodiversitas J Biol Divers. 2018;19:947-54.

23. Jati Kusuma R, Ermamilia A. Fortification of tempeh with encapsulated iron improves iron status and gut microbiota composition in iron deficiency anemia condition. Nutr Food Sci. 2018;48:962-72.

24. Cempaka L, Eliza N, Ardiansyah A, Handoko DD, Astuti RM. Proximate composition, total phenolic content, and sensory analysis of rice bran tempeh. Makara J Sci. 2018;22:89-94.

25. McCleary BV, DeVries JW, Rader JI, Cohen G, Prosky L, Mugford DC, et al. Determination of insoluble, soluble, and total dietary fiber (CODEX Definition) by enzymatic-gravimetric method and liquid chromatography: Collaborative study. J AOAC Int. 2012;95(3):824-44. https://doi.org/10.5740/jaoacint. cs2011_25 PMid:22816275

26. Arifin WN, Zahiruddin WM. Sample size calculation in animal studies using resource equation approach. Malays J Med Sci. 2017;24(5):101-5. https://doi.org/10.21315/mjms2017.24.5.11 PMid:29386977

27. Ghasemi A, Khalifi S, Jedi S. Streptozotocin-nicotinamideinduced rat model of type 2 diabetes (review). Acta Physiol Hung. 2014;101(4):408-20. https://doi.org/10.1556/ APhysiol.101.2014.4.2 PMid:25532953

28. Sivixay S, Bai G, Tsuruta T, Nishino N, Sivixay S, Bai G, et al. Cecum microbiota in rats fed soy, milk, meat, fish, and egg proteins with prebiotic oligosaccharides. AIMS Microbiol. 2021;7(1):1-12. https://doi.org/10.3934/microbiol.2021001 PMid:33659765

29. Ahnan-Winarno AD, Cordeiro L, Winarno FG, Gibbons J, Xiao $\mathrm{H}$. Tempeh: A semicentennial review on its health benefits, fermentation, safety, processing, sustainability, and affordability. Compr Rev Food Sci Food Saf. 2021;20(2):1717-67. https://doi. org/10.1111/1541-4337.12710 PMid:33569911

30. Efriwati, Suwanto A, Rahayu G, Nuraida L. Population dynamics of yeasts and lactic acid bacteria ( $\mathrm{LAB}$ ) during tempeh production. HAYATI J Biosci. 2013;20:57-64.

31. Yan Y, Wolkers-Rooijackers J, Nout MJ, Han B. Microbial diversity and dynamics of microbial communities during back-slop soaking of soybeans as determined by PCR-DGGE and molecular cloning. World J Microbiol Biotechnol. 2013;29(10):1969-74. https://doi.org/10.1007/s11274-013-1349-6 PMid:23576016

32. Vig AP, Walia A. Beneficial effects of Rhizopus oligosporus fermentation on reduction of glucosinolates, fibre and phytic acid in rapeseed (Brassica napus) meal. Bioresour Technol. 2001;78(3):309-12. https://doi.org/10.1016/ s0960-8524(01)00030-x PMid:11341693

33. Nurdini AL, Nuraida L, Suwanto A, Suliantari. Microbial growth dynamics during tempe fermentation in two different home industries. Int Food Res J. 2015;22(4):1668-74.

34. Starzyńska-JaniszewskaA, Duliński R, StodolakB. Fermentation with edible rhizopus strains to enhance the bioactive potential of hull-less pumpkin oil cake. Molecules. 2020;25:5782.

35. Yuksekdag Z, Acar BC, Aslim B, Tukenmez U. $\beta$-Glucosidase activity and bioconversion of isoflavone glycosides to aglycones by potential probiotic bacteria. Int $\mathrm{J}$ Food 
Prop. 2017;20:S2878-86.

36. Soka S, Suwanto A, Sajuthi D, Rusmana I. Impact of tempeh supplementation on gut microbiota composition in spraguedawley rats. Res J Microbiol. 2014;9:189-98.

37. Guadamuro L, Azcárate-Peril MA, Tojo R, Mayo B, Delgado S. Use of high throughput amplicon sequencing and ethidium monoazide dye to track microbiota changes in an equolproducing menopausal woman receiving a long-term isoflavones treatment. AIMS Microbiol. 2019;5(1):102-16. https://doi. org/10.3934/microbiol.2019.1.102

PMid:31384706

38. Vacca M, Celano G, Calabrese FM, Portincasa P, Gobbetti M, de Angelis $M$. The controversial role of human gut lachnospiraceae. Microorganisms. 2020;8(4):573. https://doi. org/10.3390/microorganisms 8040573

PMid:32326636

39. Mayo B, Vázquez L, Flórez AB. Equol: A bacterial metabolite from the daidzein isoflavone and its presumed beneficial health effects. Nutrients. 2019;11(9):2231. https://doi.org/10.3390/ nu11092231

PMid:31527435

40. de Filippo C, Cavalieri D, Di Paola M, Ramazzotti M, Poullet JB Massart $\mathrm{S}$, et al. Impact of diet in shaping gut microbiota revealed by a comparative study in children from Europe and rural Africa. Proc Natl Acad Sci USA. 2010;107(33):14691-6. https://doi.org/10.1073/pnas.1005963107

PMid:20679230

41. Ruengsomwong S, La-ongkham O, Jiang J, Wannissorn B, Nakayama J, Nitisinprasert S. Microbial community of healthy thai vegetarians and non-vegetarians, their core gut microbiota, and pathogen risk. J Microbiol Biotechnol. 2016;26(10):1723-35. https://doi.org/10.4014/jmb.1603.03057

PMid:27381339

42. Jain $\mathrm{A}, \mathrm{Li} \mathrm{XH}$, Chen WN. Similarities and differences in gut microbiome composition correlate with dietary patterns of Indian and Chinese adults. AMB Express. 2018;8:104. https:// doi.org/10.1186/s13568-018-0632-1

PMid:29936607

43. Kovatcheva-Datchary $P$, Nilsson A, Akrami R, Lee YS, de Vadder F, Arora T, et al. Dietary fiber-induced improvement in glucose metabolism is associated with increased abundance of prevotella. Cell Metab. 2015;22(6):971-82. https://doi. org/10.1016/j.cmet.2015.10.001

PMid:26552345

44. Tomova A, Bukovsky I, Rembert E, Yonas W, Alwarith J, Barnard ND, et al. The effects of vegetarian and vegan diets on gut microbiota. Front Nutr. 2019;6:47. https://doi.org/10.3389/ fnut.2019.00047

PMid:31058160 